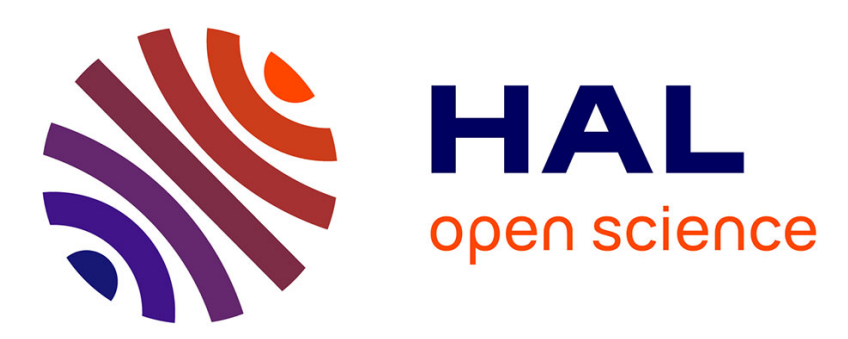

\title{
Optimization of open circuit voltage in amorphous silicon solar cells with mixed-phase (amorphous + nanocrystalline) p-type contacts of low nanocrystalline content
}

J. M Pearce, N. Podraza, R. W. Collins, M. M Al-Jassim, K M Jones, J. Deng, C R Wronski

\section{To cite this version:}

J. M Pearce, N. Podraza, R. W. Collins, M. M Al-Jassim, K M Jones, et al.. Optimization of open circuit voltage in amorphous silicon solar cells with mixed-phase (amorphous+nanocrystalline) ptype contacts of low nanocrystalline content. Journal of Applied Physics, 2007, 101 (11), pp.114301. 10.1063/1.2714507 . hal-02120516

\section{HAL Id: hal-02120516 https://hal.science/hal-02120516}

Submitted on 6 May 2019

HAL is a multi-disciplinary open access archive for the deposit and dissemination of scientific research documents, whether they are published or not. The documents may come from teaching and research institutions in France or abroad, or from public or private research centers.
L'archive ouverte pluridisciplinaire HAL, est destinée au dépôt et à la diffusion de documents scientifiques de niveau recherche, publiés ou non, émanant des établissements d'enseignement et de recherche français ou étrangers, des laboratoires publics ou privés. 


\title{
Optimization of open circuit voltage in amorphous silicon solar cells with mixed-phase (amorphous + nanocrystalline) p-type contacts of low nanocrystalline content
}

\author{
J. M. Pearce ${ }^{a)}$ \\ Physics Department, Clarion University of Pennsylvania, Clarion, Pennsylvania 16214
}

N. Podraza and R. W. Collins

University of Toledo, Toledo, Ohio 43606

M. M. Al-Jassim and K. M. Jones

National Renewable Energy Laboratory, 1617 Cole Boulevard, Golden, Colorado 80401

J. Deng and C. R. Wronski

Center for Thin Film Devices, The Pennsylvania State University, University Park, Pennsylvania 16802

(Received 8 December 2006; accepted 22 January 2007; published online 1 June 2007)

\begin{abstract}
Both the origins of the high open circuit voltages $\left(V_{\mathrm{OC}}\right)$ in amorphous silicon solar cells having $p$ layers prepared with very high hydrogen dilution and the physical structure of these optimum $p$ layers remain poorly understood topics, with several studies offering conflicting views. This work attempts to overcome the limitations of previous studies by combining insights available from electronic measurements, real time spectroscopic ellipsometry, atomic force microscopy, and both high-resolution transmission electron microscopy (TEM) and dark field TEM of cross sections of entire solar cells. It is found that solar cells fabricated with $p$ layers having a low volume fraction of nanocrystals embedded in a protocrystalline $\mathrm{Si}: \mathrm{H}$ matrix possess lower recombination at the $i / p$ interface than standard cells and deliver a higher $V_{\mathrm{OC}}$. The growth of the $p$ layers follows a thickness evolution in which pure protocrystalline character is observed at the interface to the $i$ layer. However, a low density of nanocrystallites nucleates with increasing thickness. The advantages offered by the protocrystalline character associated with the amorphous phase of the mixed-phase (amorphous+nanocrystalline) $p$ layers prepared with excess $\mathrm{H}_{2}$ dilution account for the improved $V_{\mathrm{OC}}$ of the optimum $p$ layers. In this model, the appearance of a low volume fraction of nanocrystals near the top transparent conductor interface is proposed to be incidental to the high $V_{\mathrm{OC}}$. (C) 2007 American Institute of Physics. [DOI: 10.1063/1.2714507]
\end{abstract}

\section{INTRODUCTION}

High efficiency hydrogenated amorphous silicon $(a-\mathrm{Si}: \mathrm{H}) \quad n-i-p$ solar cells fabricated with rf plasmaenhanced chemical vapor deposition (PECVD) utilize a $p$-type doped $\mathrm{Si}: \mathrm{H}$ layer deposited at low temperatures $(T$ $\leqslant 200{ }^{\circ} \mathrm{C}$ ) using high hydrogen-to-silane flow ratios $(R$ $\left.\equiv\left[\mathrm{H}_{2}\right] /\left[\mathrm{SiH}_{4}\right]\right)$ to achieve high open circuit voltages $\left(V_{\mathrm{OC}}\right.$ 's). ${ }^{1-3}$ The mechanism responsible for the high $V_{\mathrm{OC}}$ in solar cells with such high hydrogen diluted $p$ layers and the physical structure of these optimum $p$ layers remain poorly understood, with several studies offering conflicting views. ${ }^{2-6}$ There are three leading explanations of the microstructure that results in the performance enhancement observed with high hydrogen dilution $p$ layers: (i) microcrystalline silicon $(\mu \mathrm{c}-\mathrm{Si}: \mathrm{H})$, (ii) high density nanocrystalline silicon (nc-Si:H), and (iii) protocrystalline $a-\mathrm{Si}: \mathrm{H} /$ low density nc-Si:H.

An early investigation by Guha et al. proposed that the optimal top-contact $p$ layers in $n-i-p$ solar cells were fabricated from $\mu \mathrm{c}-\mathrm{Si}: \mathrm{H}^{1}{ }^{1}$ The improved overall cell perfor-

\footnotetext{
${ }^{a)}$ Author to whom correspondence should be addressed; electronic mail: jpearce@clarion.edu
}

mance with a $\mu \mathrm{c}-\mathrm{Si}: \mathrm{H} p$ layer was explained by an increase in the built-in potential $\left(V_{\mathrm{bi}}\right)$ of the top junction as well as decreasing the series resistance and optical absorption. ${ }^{1}$ This study was handicapped by the evolution of microstructure in PECVD growth of Si:H with high hydrogen dilution ratios. Initially, $a-\mathrm{Si}: \mathrm{H}$ material is deposited, but as the bulk thickness layer increases small nanocrystals are nucleated, preferentially grow into microcrystals, and eventually coalescence into a $\mu \mathrm{c}-\mathrm{Si}: \mathrm{H}$ film. ${ }^{7-9}$ In this study, the films that were characterized by optical absorption and conductivity were necessarily thick $(>100 \mathrm{~nm})$, and thus it is likely that they evolved to coalesced $\mu \mathrm{c}-\mathrm{Si}: \mathrm{H}$. On the other hand, the $p$ layers incorporated into the solar cells themselves were extremely thin $(\sim 10 \mathrm{~nm})$ and may not have nucleated any nanocrystals. Reflection high-energy electron diffraction (RHEED) patterns were also presented as evidence that the optimum $p$ layers were $\mu \mathrm{c}-\mathrm{Si}: \mathrm{H}^{3}$ However, RHEED is very surface sensitive and thus fails to probe the $p$ layer material closest to the $i / p$ interface. It is likely that the films determined as $\mu \mathrm{c}-\mathrm{Si}: \mathrm{H}$ initially started as $a-\mathrm{Si}: \mathrm{H}$ and evolved greater volume fractions of nanocrystals with thickness until the surface of the $p$-layer appeared microcrystalline with RHEED.

Recently, Du et al. reported results of a structural analy- 
sis of the high $R p$ layers found to optimize $V_{\mathrm{OC}}$ in $a-\mathrm{Si}: \mathrm{H}$ $n-i-p$ solar cells. ${ }^{10}$ This analysis applied Raman scattering spectroscopy and high-resolution transmission electron microscopy (HRTEM). The Raman scattering measurements were performed on $300 \mathrm{~nm}$ thick $p$ layers deposited on glass substrates and measured from the glass side. The result revealed a crystalline volume fraction of $11 \%$ for $p$ layers optimized for highest $V_{\mathrm{OC}}$ in the solar cell structure. The limitation of such a Raman study was recognized. In fact, because the absorption depth is up to $100 \mathrm{~nm}$ for the $488 \mathrm{~nm}$ laser line used by these authors, the Raman scattering signature of crystallites may have occurred from the region of the film deeper than $15 \mathrm{~nm}$, the $p$ layer thickness. Thus, another focus of this literature study was HRTEM characterization. This analysis was performed on a more realistic structure: a $15 \mathrm{~nm}$ thick $p$ layer grown on a $15 \mathrm{~nm}$ intrinsic $a$-Si: $\mathrm{H}$ layer which was intended to correspond to the standard $i / p$ interface in device fabrication. ${ }^{10}$ The surface nanocrystallite density was found to be approximately $50 \%$ for the $p$-layer conditions providing the highest $V_{\mathrm{OC}}$ in the actual cell structure. However, one potential problem that may still limit the relevance of this result is the fact that the $15 \mathrm{~nm} i$ layer was prepared on glass. If this $i$ layer is not deposited under the same conditions as in the solar cell structure, i.e., optimized for an amorphous $n$ layer as a substrate, the glass substrate may promote nanocrystallites or seeds for nanocrystallite development that are suppressed by the $n$ layer in the solar cell configuration. A second more general problem that will be addressed further is the relevance of observed nanocrystals to the actual device performance.

Other studies on $p$ layers for optimizing $V_{\mathrm{OC}}$ utilizing phase diagrams, ex situ spectroscopic ellipsometry (SE), and recombination determined by dark current-voltage characteristics argue for a predominantly amorphous $p$ layer in the protocrystalline regime as the optimum $p$ layer structure. ${ }^{4,6,11}$ The $a-\mathrm{Si}: \mathrm{H}$ material prepared just below the onset of nanocrystallite nucleation on the deposition phase diagram for a given desired thickness is referred to as "protocrystalline" and was previously shown to provide superior performance when used as $i$ layers of $a$-Si:H solar cells. ${ }^{12-14}$ These studies put an upper limit on the nucleation density of nanocrystals within the amorphous matrix at the sensitivity limit of the spectroscopic ellipsometer: $\sim 2 \%$ for the thin $p$ layers. ${ }^{6}$

This study builds on this previous work and overcomes the limitations of these studies by combining insights available from electronic measurements, real time spectroscopic ellipsometry (RTSE), atomic force microscopy (AFM), HRTEM, and dark field TEM of cross sections of entire solar cells to formulate a more comprehensive model for the improved $V_{\mathrm{OC}}$ observed with high hydrogen dilution $p$ layers.

\section{EXPERIMENT}

The undoped and $p$-type doped $\mathrm{Si}: \mathrm{H}$ layers utilized to develop the phase diagrams were deposited on $R$ $=\left[\mathrm{H}_{2}\right] /\left[\mathrm{SiH}_{4}\right]=0 a-\mathrm{Si}: \mathrm{H}$, which was in turn deposited on crystalline $\mathrm{Si}$ using single-chamber rf PECVD and were measured in real time using a rotating-compensator multichannel ellipsometer for RTSE. ${ }^{15}$ Underlying $a-\mathrm{Si}: \mathrm{H}$ films prepared with $R$ values from 0 to 10 were verified to be fully amorphous using RTSE and HRTEM. The substrate temperature $T$, rf plasma power $P$, and $\mathrm{SiH}_{4}$ flow $F$ were set at $T$ $=200{ }^{\circ} \mathrm{C}, P=0.8 \mathrm{~W} / \mathrm{cm}^{2}$, and $F=1 \mathrm{SCCM}$ (SCCM denotes cubic centimeter per minute at STP), respectively. In addition, the $\mathrm{H}_{2}$-dilution ratio $R$, doping gas ratio $D$, and total pressure $p_{\text {tot }}$ were set within the ranges $R \approx 50-200, D$ $=\left[\mathrm{BF}_{3}\right] /\left[\mathrm{SiH}_{4}\right] \approx 0-0.2$, and $p_{\text {tot }} \approx 0.3-0.9$ Torr, respectively. For these Si:H layers, $P$ was an order of magnitude higher than that for the underlying $a-\mathrm{Si}: \mathrm{H}$ films. Previous studies have found excellent agreement between deposition phase diagrams obtained by RTSE for single-chamber deposition and those obtained by ex situ SE and AFM for multichamber deposition, applying similar process parameters in each case ${ }^{16}$ In order to confirm the actual microstructure of these $p$ layers, a series of AFM and TEM studies were performed on the following cell structures: (i) [c-Si substrate]/ $[R=10 i$-type $a$-Si:H $(120 \mathrm{~nm})] /[D=0.2 p$-type Si:H $(20-$ $30 \mathrm{~nm})]$ for AFM and plan-view TEM and (ii) $[\mathrm{c}-\mathrm{Si}$ substrate] / [ $\left.\mathrm{SiO}_{2} \quad(100 \mathrm{~nm})\right] /[$ evaporated $\mathrm{Cr} \quad(100 \mathrm{~nm})] /$ [n-type $a$-Si:H $(25 \mathrm{~nm})] /[R=10 i$-type $a$-Si:H $(100 \mathrm{~nm})] /$ [p-type protocrystalline-Si:H $(25 \mathrm{~nm})]$ for both the surface and cross section for TEM. The cell structures were examined in a noncontact mode with a Park Scientific M5 AFM over a $1 \times 1 \mu \mathrm{m}^{2}$ area. The high-resolution and dark field TEM imaging was performed at the National Renewable Energy Laboratory. The $n-i-p$ structures in this study were deposited by rf PECVD at substrate temperature of $200{ }^{\circ} \mathrm{C}$ with bulk $R=10$ intrinsic layers under the previously described conditions. ${ }^{17}$ The $p$-Si:H cell structures consisted of glass $/ \mathrm{Cr} /[n$-type $\mu \mathrm{c}-\mathrm{Si}: \mathrm{H} \quad(35 \mathrm{~nm})] /[i$-type $a$-Si:H $(400 \mathrm{~nm})] /[p$-type $\mathrm{Si}: \mathrm{H}(\sim 20 \mathrm{~nm})] / \mathrm{ITO}$ (ITO denotes indium tin oxide), where the $p$ layers were deposited with $R$ varying from 100 to 200 , and the doping ratio was fixed at $D=\left[\mathrm{BF}_{3}\right] /\left[\mathrm{H}_{2}\right]=0.2$. ${ }^{11}$ The ITO top-contact layers were sputter-deposited at $170{ }^{\circ} \mathrm{C}$ and the areas of the structures tested were $0.05 \mathrm{~cm}^{2}$. The cells were characterized using dark current-voltage $\left(J_{D^{-}} V\right)$ as well as light current-voltage $(I-V)$ measurements under 1 sun illumination conditions. Both of these measurements were performed at $25^{\circ} \mathrm{C}$ using a three-point probe technique in order to eliminate any extraneous series resistance effects, allowing the $J_{D^{-}} V$ characteristics to be accurately characterized at high forward bias. ${ }^{18}$

\section{RESULTS}

The microstructure and its evolution for the $p-\mathrm{Si}: \mathrm{H}$ layers in this study were characterized with RTSE. ${ }^{19}$ Guided by previous studies, ${ }^{11}$ a series of five $p$ layers were deposited with $D=0.2$ and $R=100,125,150,175$, and 200 on $a-\mathrm{Si}: \mathrm{H} i$ layers with $R=0$. Figures 1 (a) (for $R=100,125$, and 150) and 1 (b) (for $R=150,175$, and 200) show the roughness layer thickness $\left(d_{s}\right)$ as a function of accumulated bulk layer thickness $\left(d_{b}\right)$ determined by RTSE. Figure 1(a) shows that the surface roughness layer on the $R=100$ is relatively stable to a thickness of $\sim 90 \mathrm{~nm}$ at which point a roughening onset indicates a transition to mixed-phase $\mathrm{Si}: \mathrm{H}$ growth. For the $R=125$ and 150 films, this mixed-phase roughening onset has shifted to smaller thicknesses $(\sim 20 \mathrm{~nm})$ and a shoulder 

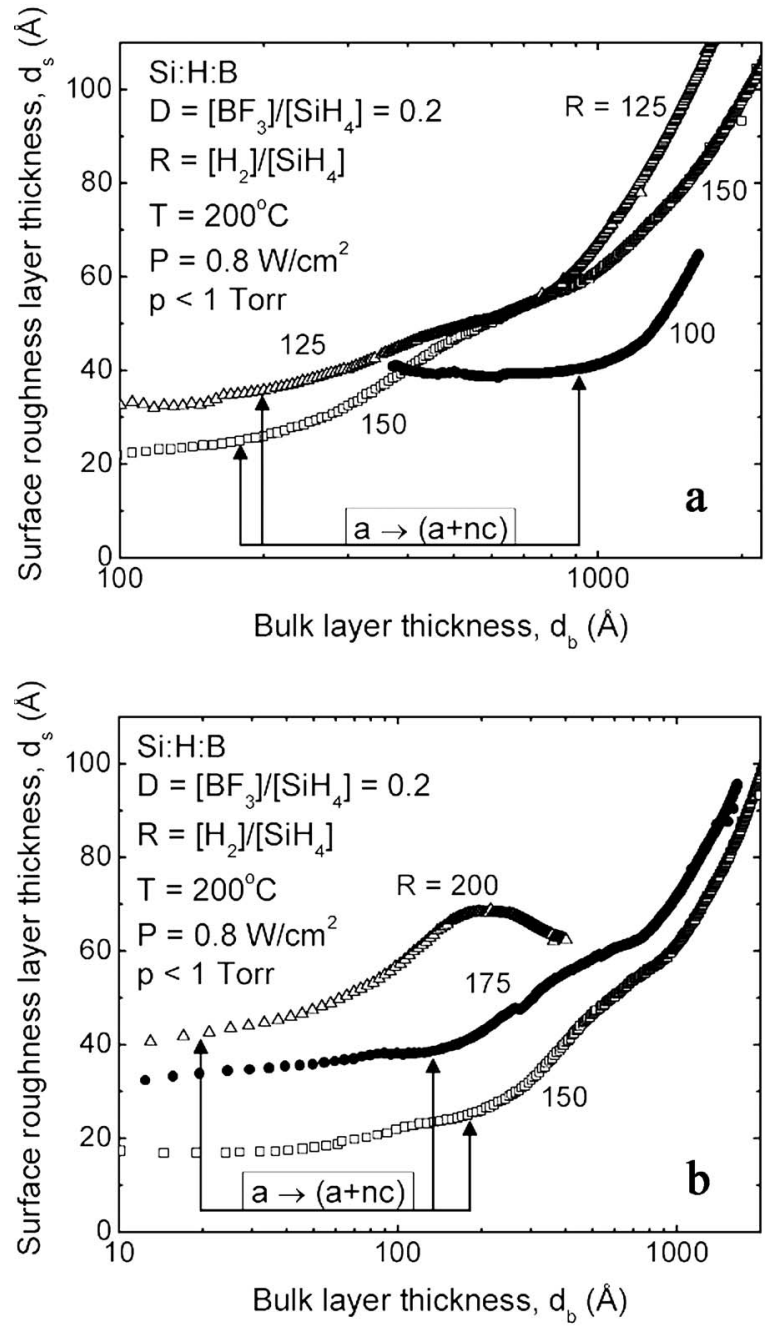

FIG. 1. (a) Roughness layer thickness $\left(d_{s}\right)$ as a function of accumulated bulk layer thickness $\left(d_{b}\right)$ determined by RTSE for $p$ layers of $D=0.2$ and $R$ $=100,125$, and 150. (b) Roughness layer thickness $\left(d_{s}\right)$ as a function of accumulated bulk layer thickness $\left(d_{b}\right)$ determined by RTSE for $p$ layers of $D=0.2$ and $R=150,175$, and 200 .

near $80 \mathrm{~nm}$ develops, the latter indicating a transition to single-phase microcrystalline $\mathrm{Si}: \mathrm{H}$. In order to extract the information in Fig. 1(a) for the lower $R p$ layers $(R=100$ and $125)$, it was necessary to incorporate void structures whose depth profiles are depicted in Fig. 2, as extracted through a

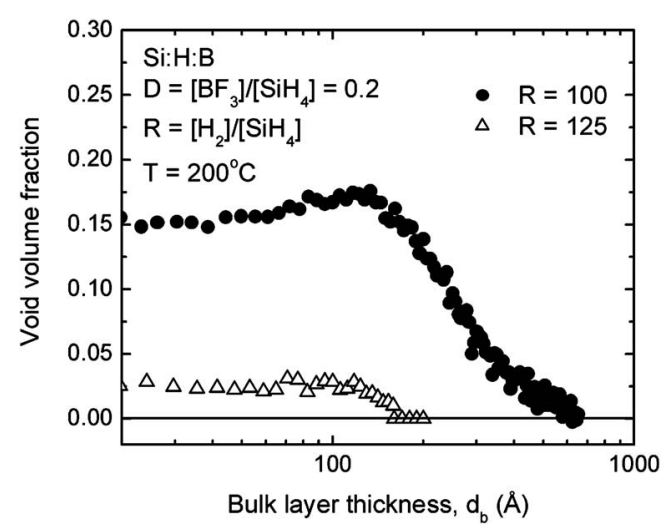

FIG. 2. Void volume fraction as a function of bulk layer thickness $\left(d_{b}\right)$ extracted through virtual interface analysis of the RTSE data in Fig. 1.

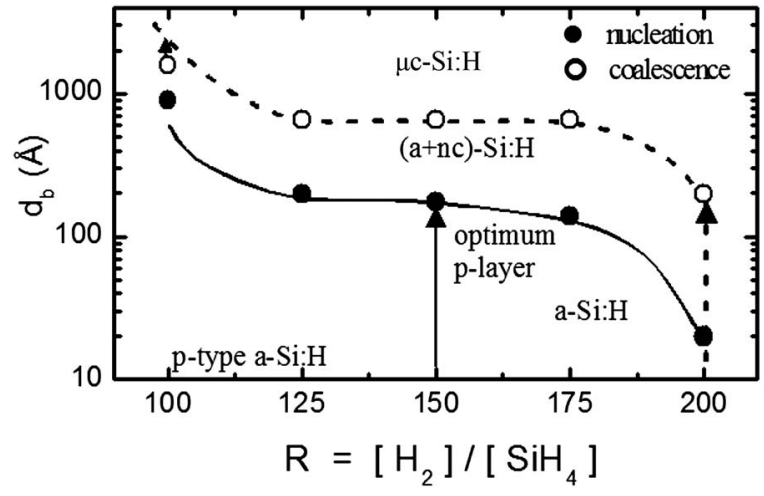

FIG. 3. Extended phase diagram for $D=0.2, p-\mathrm{Si}: \mathrm{H}$ as a function of hydrogen dilution ratio $(R)$ and accumulated bulk thickness $\left(d_{b}\right)$.

virtual interface analysis of the RTSE data. Figure 2 shows that a significant volume fraction of voids is trapped within $\sim 50 \mathrm{~nm}$ of the interface to the $i$ layer in the $R=100$ film, and these are eliminated with increasing $R$ as the mixed-phase transition is approached for the desired $p$ layer thickness. In Fig. 1(b), clearer shifts to decreasing thickness in the mixedphase roughening onset and the single-phase shoulder are observed. The interpretation of the roughness evolution in terms of mixed-phase and single-phase transitions are supported by analyses of the deduced dielectric functions of the films and summarized on the deposition phase diagram of Fig. 3.

The full deposition phase diagram for the $p$-type doped layer with $D=0.2$ and $100 \leqslant R \leqslant 200$ shown in Fig. 3 includes both the amorphous-to-(mixed-phase)-amorphous/ nanocrystalline $\mathrm{Si}: \mathrm{H}$ transition thickness [designated by filled circles and a solid line] and the (mixed-phase)-to(single-phase) $\mu \mathrm{c}-\mathrm{Si}: \mathrm{H}$ transition thickness [designated by open circles and a dashed line]. The phase diagram shows that for $R=100$, the film grows initially as $a-\mathrm{Si}: \mathrm{H}$ and crystallites begin to nucleate from the amorphous phase after a bulk layer thickness of $90 \mathrm{~nm}$. The resulting mixed-phase amorphous/nanocrystalline hydrogenated silicon (a/nc$\mathrm{Si}: \mathrm{H})$ continues to grow until the final film thickness of $150 \mathrm{~nm}$ is reached. The open symbol and the upward arrow for $R=100$ indicate that the transition to single-phase $\mu \mathrm{c}-\mathrm{Si}: \mathrm{H}$ must occur for thicknesses greater than the designated $150 \mathrm{~nm}$, as evidenced by the lack of a coalescence shoulder in the data of Fig. 1(a). In contrast, at $R=200$, the transition from predominantly $a-\mathrm{Si}: \mathrm{H}$ to mixed-phase $a / \mathrm{nc}-\mathrm{Si}: \mathrm{H}$ occurs at an accumulated thickness of $2 \mathrm{~nm}$. Also, the transition to single-phase $\mu \mathrm{c}-\mathrm{Si}: \mathrm{H}$ occurs at $20 \mathrm{~nm}$ and is highlighted with a dashed line as a function of $R$. The crystalline volume fraction as a function of thickness for a given $R$ value was determined by RTSE using a previously described method. ${ }^{20}$ The optimal $p$-layer material for a thickness of $20 \mathrm{~nm}$ is denoted by the solid arrow at $R=150$.

In Figs. 4(a)-4(c), the surface topology of a $1 \times 1 \mu \mathrm{m}^{2}$ scan provided by an AFM in noncontact mode is shown for $p$ layers in the configuration [c-Si substrate $] /[R=10 i$-type $a$-Si:H $(120 \mathrm{~nm})] /[D=0.2 p$-type Si:H $(20-30 \mathrm{~nm})]$ with $p$-layer $\mathrm{H}_{2}$-dilution levels of $R=100, R=150$, and $R=200$, respectively. It is evident that the $R=100 p$ layer of Fig. 4(a) 
(a)

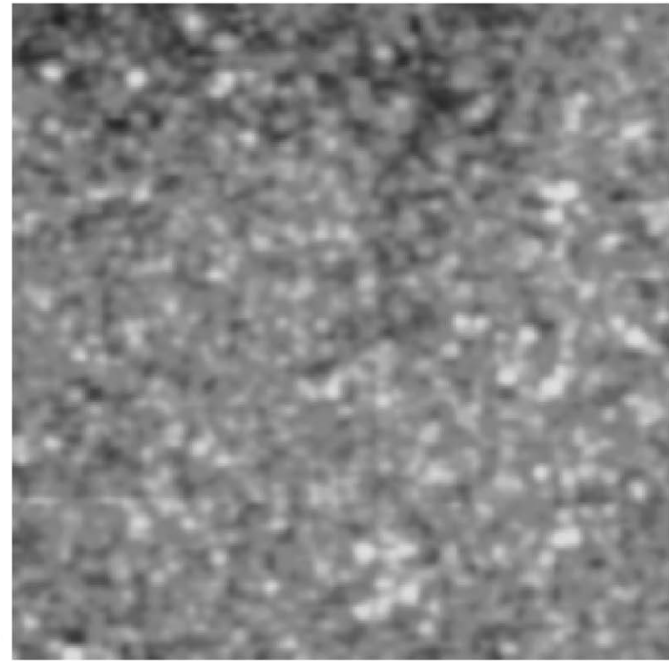

(b)

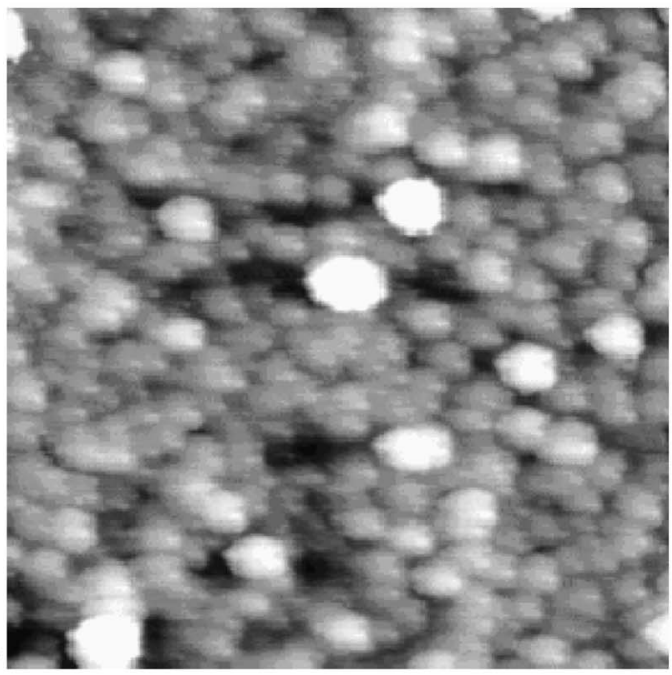

(c)

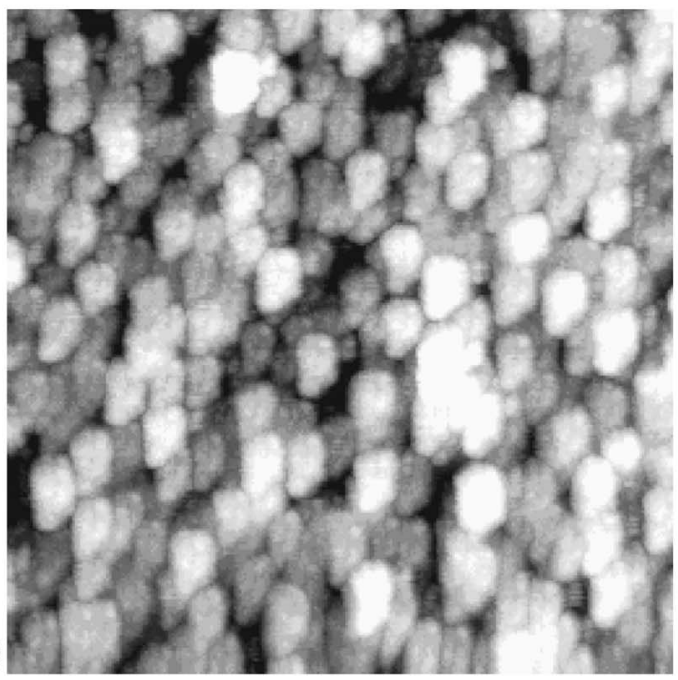

FIG. 4. $1 \times 1 \mu \mathrm{m}^{2}$ AFM images of (a) $R=100$, (b) $R=150$, and (c) $R=200$ for structures on a c-Si substrate/120 nm $i, R=10 / 20-30 \mathrm{~nm} p$ at $D=0.2$.

with a rms surface roughness of $0.63 \mathrm{~nm}$ is amorphous and that the $R=200 p$ layer of Fig. 4(c) with a rms surface roughness of $2.18 \mathrm{~nm}$ is fully $\mu \mathrm{c}-\mathrm{Si}: \mathrm{H}$. For the $p$ layer of Fig. 4(b) with an rms surface roughness of $1.29 \mathrm{~nm}$, however, it is more difficult to ascertain the exact nature of the material, but it appears that there are several nanocrystals per $\mu \mathrm{m}^{2}$ of
TABLE I. The 1 sun open circuit voltages, crystalline volume fraction from RTSE, and rms surface roughness from AFM (Fig. 4) of $D=0.2 p$ layers for hydrogen dilution ratios $R=100-200$.

\begin{tabular}{lccc}
\hline \hline & & $\begin{array}{c}\text { Crystalline } \\
\text { volume } \\
\text { fraction }(\%)\end{array}$ & $\begin{array}{c}\text { rms } \\
\text { AFM (nm) }\end{array}$ \\
\hline 100 & $V_{\mathrm{OC}}$ & $<2$ & 0.63 \\
125 & 0.92 & $<2$ & \\
150 & 0.93 & $<2$ & 1.29 \\
175 & 0.96 & 30 & 2.18 \\
200 & 0.94 & 63 & 26 \\
\hline \hline
\end{tabular}

surface. This was confirmed with multiple scans over different locations on identically prepared samples. In addition, a complete solar cell (c-Si $/ \mathrm{SiO}_{2} / \mathrm{Cr} / n-i-p$ ) for the $R=150$ was imaged. The rms surface roughness value of $2.36 \mathrm{~nm}$ obtained for this cell is within experimental error, the same as that of an amorphous material deposited on such a multilayer stack. The AFM results are thus consistent with the RTSE results, namely, that the optimal $p$ layer is protocrystalline in nature with a volume fraction of nanocrystallites below the detection limit of the optical probe.

The materials characterized in Figs. 1-4 were used as $20 \mathrm{~nm} p$ contacts in state-of-the-art $n-i-p$ solar cells. The 1 sun $V_{\mathrm{OC}}$ values, the crystalline volume fraction as determined by ex situ SE, and the rms surface roughness determined by AFM are shown in Table I for five values of $R$. The highest $V_{\mathrm{OC}}$ is achieved by the cell having a $R=150 p$ layer that has protocrystalline character such that the growth process is very close to the transition to the mixed ( $a$ $+\mathrm{nc})-\mathrm{Si}: \mathrm{H}$ phase for the $20-30 \mathrm{~nm}$ thickness of the layer. ${ }^{21}$ For $R=100$, the $p$ layer is amorphous throughout its thickness and the $20 \mathrm{~nm}$ thickness is far from the transition into the mixed phase. On the other hand, for the $R=200$ cell, the $p$ layer develops into a mixed $(a+\mathrm{nc})-\mathrm{Si}: \mathrm{H}$ phase almost from the beginning of the deposition and evolves into a purely microcrystalline phase at the thickness of $\sim 20 \mathrm{~nm}$.

In order to obtain a more direct description of the phase of the optimum $p$-layer material with $R=150$ and thickness of 20-30 nm, selected area diffraction (SAD) and TEM imaging were also utilized. In Fig. 5, the SAD pattern also agrees with the RTSE data and indicates a predominantly amorphous material. However, TEM dark field imaging of the optimized $p$-layer $(R=150, D=0.2)$ samples revealed some small $(\sim 10 \mathrm{~nm})$ nanocrystallites embedded in the amorphous matrix, as seen in the plan view in Fig. 6. In Fig. 7, the high-resolution examination of the crystallites in Fig. 6 clearly displays the lattice image with the Si (111) fringes. In aggregate, these results all indicate that the $R=150 p$ layer contains a low density of nanocrystallites in an amorphous matrix. Finally, to confirm the protocrystalline growth view provided by RTSE, cross sectional TEM images of the cell were taken with a $p$ layer prepared under the optimum conditions but to somewhat greater thickness $(40 \mathrm{~nm})$ than that in the device in order to track the evolution of the crystallites. As can be seen in Fig. 8, nanocrystallites are clearly visible with dark field imaging. The nanocrystallites appear to nucleate after a thickness of about $20 \mathrm{~nm}$, in consistency 


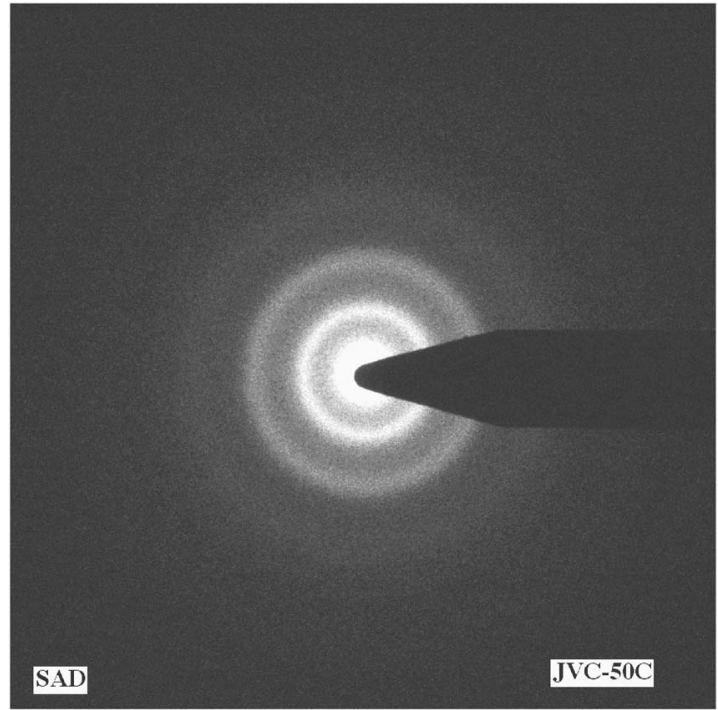

FIG. 5. Selected area diffraction (SAD) pattern for $D=0.2$ and $R=150$ p-layer film

with the phase diagram of Fig. 3 and then grow as cones with increasing diameter with accumulated bulk thickness. Thus, for a $25 \mathrm{~nm} p$ layer in a device there is a small nanocrystalline volume fraction near the top of the layer, whereas the material adjacent to the $i / p$ interface is purely protocrystalline.

\section{DISCUSSION}

The aggregate of results from RTSE, AFM, SAD, HRTEM, and dark field TEM clearly point to the highest $V_{\mathrm{OC}}$ being obtained with a protocrystalline $a-\mathrm{Si}: \mathrm{H} / \mathrm{nc}-\mathrm{Si}: \mathrm{H} p$ layer that is deposited at a maximum $R$ value, allowing the desired thickness to be obtained while only growing a relatively small volume fraction of nanocrystallites. There are, however, several key factors that have a synergistic effect that combine to determine the role this microstructure has on

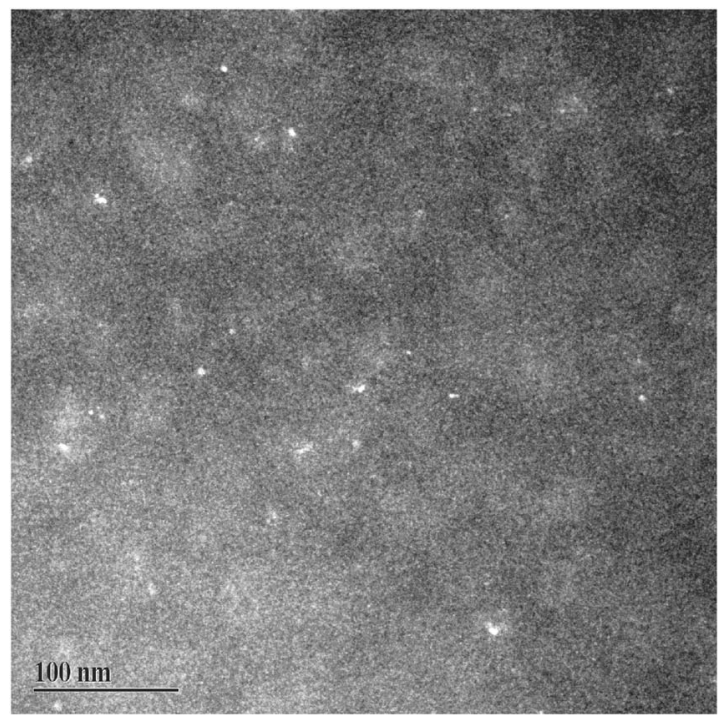

FIG. 6. Dark field plan-view TEM image of the optimal $R=150 p$-layer material showing nanocrystallites of $10-25 \mathrm{~nm}$ diameter. The structure is on a c-Si substrate/120 nm $i, R=10 / 20 \mathrm{~nm} p$ at $D=0.2$.

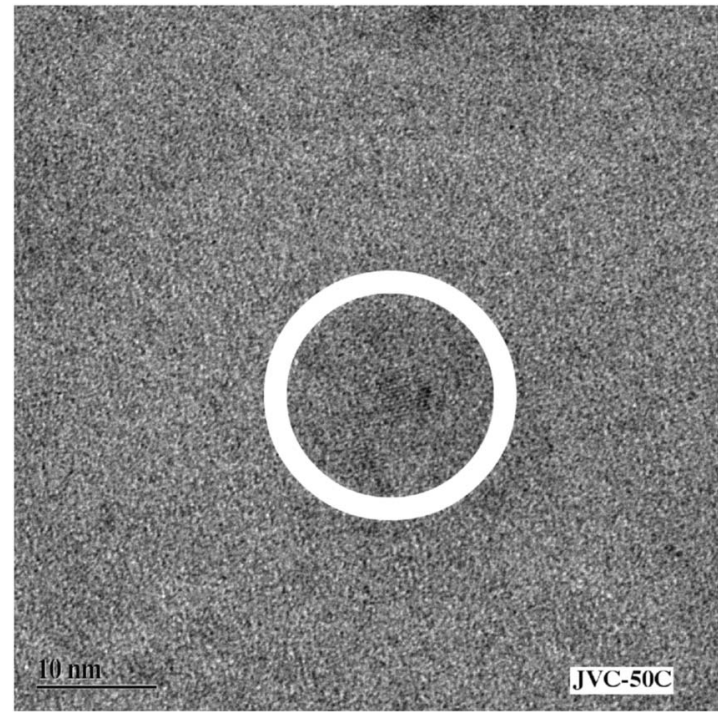

FIG. 7. High-resolution TEM image of the optimal $R=150 p$-layer material clearly showing the $\mathrm{Si}$ (111) fringes within the nanocrystal in the middle of the image.

$V_{\mathrm{OC}}$ : (1) modification of the underlying $i$ layer due to exposure to the $\mathrm{H}_{2}$-rich plasma of the $p$ layer, (2) $i / p$ interface characteristics that control recombination, and (3) increased ordering and band gap of the protocrystalline $p$ layer material due to enhanced $\mathrm{H}_{2}$ dilution.

The deposition of optimal $p$ layers with high hydrogen dilution may modify the sublayer of the intrinsic material. The increased flux of atomic hydrogen in the plasma due to the large hydrogen dilution ratio can enter the $i$ layer in the several initial atomic monolayers of $p$-layer deposition and be incorporated into the amorphous network. The increased hydrogen content of the resultant $i$ layer would be expected to have a larger band gap and narrower band tails near the

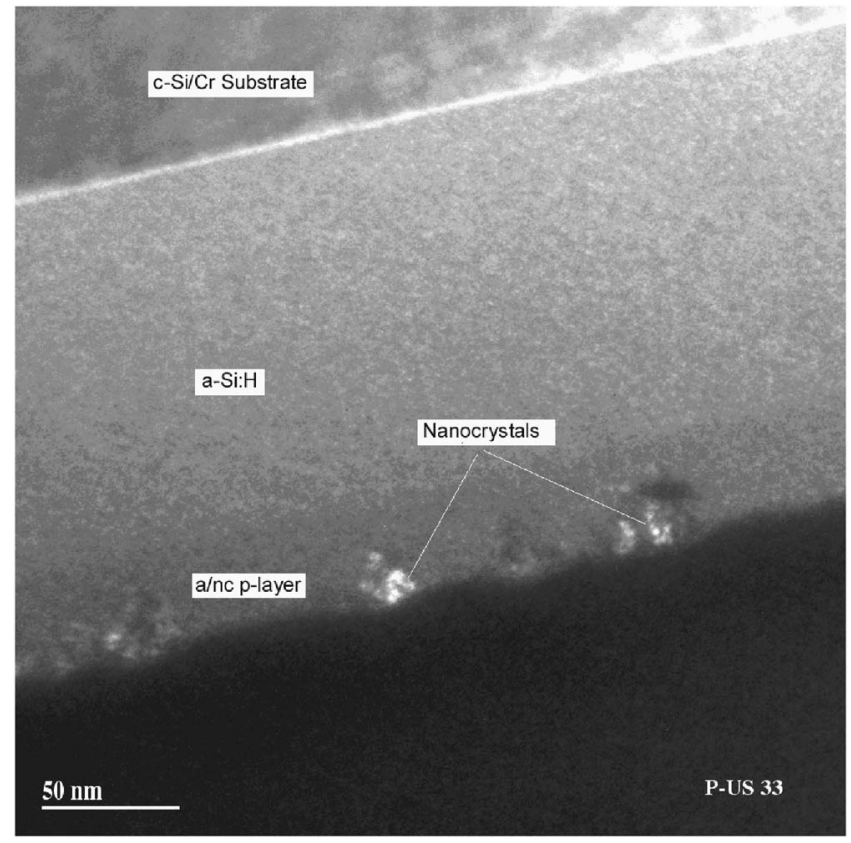

FIG. 8. Cross sectional TEM images $\mathrm{c}-\mathrm{Si}$ substrate/120 $\mathrm{nm} i, R$ $=10 / 20-30 \mathrm{~nm} p(R=150, D=0.2)$. Optimal case for $n-i-p p$ layers $\left(V_{\mathrm{OC}}\right.$ $=0.96 \mathrm{~V})$. 
$i / p$ interface than an $i$ layer covered with a low- $R p$ layer. $^{22,23}$ These subsurface reactions, which improve the $i$ layer adjacent to the $i / p$ interface, are analogous to those obtained with the protocrystalline $a-\mathrm{Si}: \mathrm{H}$ buffer layers used in solar cells with $a$-SiC:H $p$ layers. $^{24}$ The significant changes in the band gap of $\sim 20 \mathrm{~nm}$ in the intrinsic $a-\mathrm{Si}: \mathrm{H}$ observed during the deposition of the protocrystalline $p$ layers support this explanation. ${ }^{6}$ Likewise, the high hydrogen dilution in the optimal $p$ layer would reduce damage to the $i$ layer during the beginning of the $p$-layer deposition. This is similar to the research on the heterojunction with intrinsic thin layer (HIT) structure, ${ }^{25}$ where a crystalline silicon $i$ layer is sandwiched between a wide band gap $a$-Si:H buffer $i$ layers before depositing the $p$ and $n$ layers on either side. Finally, the larger band gap and narrower band tails in the $i / p$ interface region would lower electron hole recombination there.

Earlier work by Vlahos et al. studied the recombination at the $i / p$ interfaces on identical cells with $J_{D^{-}} V$ characteristics. ${ }^{11}$ The recombination at the $i / p$ interface depends on: (i) the densities of defects at the $i / p$ interface, (ii) the band gap in the $i / p$ region, (iii) alignment at the $i / p$ interface between the $i$ layer and the $p$ layer, and (iv) the built-in potential $\left(V_{\mathrm{bi}}\right)$. Determination of the $V_{\mathrm{bi}}$ is complicated because it is dependent on both band gap alignment between the $i$ and $p$ layers as well as the doping efficiency of the $p$ layer. These factors can work against one another. For example, the effect of moving the Fermi level as a consequence of the higher doping efficiency is counteracted by the increase in the $p$-layer band gap. In this case, when $R$ is increased from 100 to 150 in the two protocrystalline $p$ layers there is an increase in the band gap due to increased hydrogen content as well as increased doping efficiency, which could both increase the $V_{\mathrm{bi}}$. An increase in $V_{\mathrm{bi}}$ contributes to the reduction of recombination at the $i / p$ interface since it decreases the concentration of electrons in the interface region. ${ }^{17}$ Another possible reason for the significant reduction in recombination is the decreased defect state density in the $i / p$ interfaces themselves.

The recombination obtained at the $i / p$ interface with the $R=150$ protocrystalline $p$ layer is significantly smaller than that for the $R=40$ buffer layer in the $a-\mathrm{SiC}: \mathrm{H} n-i-p$ cells, the lowest achieved for those cells. ${ }^{11}$ As a consequence of this low $i / p$ interface recombination in the $R=150 p$-Si:H cell, the bulk recombination regime extends to higher voltages and gives the highest 1 sun $V_{\mathrm{OC}}$. When $R$ is increased further (from 150 to 200), the $p$ layer is immediately formed in the mixed $(a+\mathrm{nc})-\mathrm{Si}: \mathrm{H}$ phase. In this case, not only does the nature of the $i / p$ interface change, but there is also a decrease in the gap of the $p$ layer. This decrease is fairly symmetrical for the conduction and valence bands, ${ }^{26}$ so even though the doping efficiency remains high, the net band misalignment can in fact lead to a decrease of $V_{\mathrm{bi}}$ and additional detrimental $i / p$ interface recombination. ${ }^{11}$ These factors have a net negative effect on the $V_{\mathrm{OC}}$

Higher $R$ would also be expected to improve the microstructure of the protocrystalline $p$ layer, much similar to the results observed in $i$ layer materials. ${ }^{12}$ For the optimal case found in this study at $R=150$, the increased hydrogenation without the onset of major volume fraction of nanocrystallites enhances both the ordering in the material and its band gap. The results in this study show that the optimal $p$-layer material leading to higher $V_{\mathrm{OC}}$ values is a mixed-phase amorphous-nanocrystalline material. It is important to appreciate the nonhomogeneous protocrystalline nature of this material. The optimal $p$ layer is not a uniform mixed-phase material with nanocrystals equally dispersed within the $20 \mathrm{~nm}$ thickness. The nanocrystallites evolve with thickness and those on the top of the $p$ layers in the $n-i-p$ configuration may assist in making good electrical contact with the transparent conducting oxide (TCO). Overall, the results show the small volume fractions of nanocrystals in the predominantly protocrystalline material can accompany a high $V_{\mathrm{OC}}$ in the complete $n-i$ - $p$ solar cell.

\section{CONCLUSIONS}

High efficiency $a$-Si:H $n-i-p$ solar cells fabricated with rf PECVD utilize a $p$-type doped $\mathrm{Si}: \mathrm{H}$ layer deposited at low temperatures using high hydrogen-to-silane flow ratios to achieve high $V_{\mathrm{OC}}$ 's. The combined evidence of RTSE, ex situ SE, AFM, SAD, HRTEM, and dark field TEM of cross sections of entire solar cells indicate the optimal $p$-layer material leading to higher $V_{\mathrm{OC}}$ values and has a low volume fraction of nanocrystals embedded in a protocrystalline $\mathrm{Si}: \mathrm{H}$ matrix. Solar cells fabricated with $p$ layers with ( $a$ $+\mathrm{nc})-\mathrm{Si}: \mathrm{H}$ microstructure possess lower recombination at the $i / p$ interface than standard cells. The growth of the $p$ layers follows a thickness evolution in which pure protocrystalline material is observed at the interface to the $i$ layer and a low density of nanocrystallites nucleates with increasing thickness. The advantages offered by the protocrystalline character associated with the amorphous phase of the mixedphase (amorphous+nanocrystalline) $p$ layers prepared with excess $\mathrm{H}_{2}$ dilution account for the improved $V_{\mathrm{OC}}$ of the optimum $p$ layers. These advantages include sublayer modifications of the $i$ layer to increase band gap, $i$ - and $p$-layer ordering, and decreased recombination at the $i / p$ interface. In this model, the appearance of a low volume fraction of nanocrystals near the top transparent conductor interface can accompany a high $V_{\text {OC }}$.

\section{ACKNOWLEDGMENTS}

The authors would like to acknowledge the technical assistance from G. M. Ferreira and V. U. Vlahos. The authors acknowledge the support for this work from the National Renewable Energy Laboratory under Subcontract No. NDJ2-30630-01.

${ }^{1}$ S. Guha, J. Yang, P. Nath, and M. Hack, Appl. Phys. Lett. 49, 218 (1986). ${ }^{2}$ A. Banerjee, Sol. Energy Mater. Sol. Cells 36, 295 (1995).

${ }^{3}$ X. Deng, S. J. Jones, T. Liu, M. Izu, S. R. Ovshinsky, and K. Hoffman, Mater. Res. Soc. Symp. Proc. 467, 795 (1997).

${ }^{4}$ G. M. Ferreira, C. Chen, R. J. Koval, J. M. Pearce, R. W. Collins, and C. R. Wronski, J. Non-Cryst. Solids 338-340, 694 (2004).

${ }^{5}$ R. J. Koval, C. Chen, G. M. Ferreira, A. S. Ferlauto, J. M. Pearce, P. I. Rovira, C. R. Wronski, and R. W. Collins, Mater. Res. Soc. Symp. Proc. 715, A6.1 (2002).

${ }^{6}$ R. J. Koval, C. Chen, G. M. Ferreira, A. S. Ferlauto, J. M. Pearce, P. I. Rovira, R. W. Collins, and C. R. Wronski, Appl. Phys. Lett. 81, 1258 
(2002).

${ }^{7}$ J. Koh, Y. Lee, H. Fujiwara, C. R. Wronski, and R. W. Collins, Appl. Phys. Lett. 73, 1526 (1998).

${ }^{8}$ J. Koh, A. S. Ferlauto, P. I. Rovira, C. R. Wronski, and R. W. Collins, Appl. Phys. Lett. 75, 2286 (1999).

${ }^{9}$ S. Kim, J. S. Burnham, J. Koh, L. Jiao, C. R. Wronski, and R. W. Collins, J. Appl. Phys. 80, 2420 (1996).

${ }^{10}$ W. Du, X. Liao, X. Yang, X. Xiang, and X. Deng, Conference Record of the 31st IEEE Photovoltaic Specialist Conference (IEEE, New York, 2005), p. 1401.

${ }^{11}$ V. Vlahos, J. Deng, J. M. Pearce, R. J. Koval, R. W. Collins, and C. R. Wronski, Mater. Res. Soc. Symp. Proc. 762, A7.2 (2003).

${ }^{12}$ R. Koval et al., Mater. Res. Soc. Symp. Proc. 609, A15.5 (2000).

${ }^{13}$ S. Y. Myong, K. S. Lim, and J. M. Pearce, Appl. Phys. Lett. 89, 193509 (2005).

${ }^{14}$ S. Y. Myong, S. W. Kwon, K. S. Lim, M. Kondo, and M. Konagai, Appl. Phys. Lett. 88, 083118 (2006).

${ }^{15}$ R. W. Collins, J. Koh, H. Fujiwara, P. I. Rovira, A. S. Ferlauto, J. A. Zapien, C. R. Wronski, and R. Messier, Appl. Surf. Sci. 154, 217 (2000). ${ }^{16}$ R. W. Collins et al., Sol. Energy Mater. Sol. Cells 78, 143 (2003).

${ }^{17}$ R. J. Koval, C. Chen, G. M. Fereira, A. S. Ferlauto, J. M. Pearce, P. I Rovira, C. R. Wronski, and R. W. Collins, Mater. Res. Soc. Symp. Proc.
715, A6.1 (2002).

${ }^{18}$ J. Deng, J. M. Pearce, R. J. Koval, V. Vlahos, R. W. Collins, and C. R. Wronski, Appl. Phys. Lett. 82, 3023 (2003).

${ }^{19}$ J. Koh, A. S. Ferlauto, P. I. Rovira, C. R. Wronski, and R. W. Collins, Appl. Phys. Lett. 75, 2286 (1999).

${ }^{20}$ A. S. Ferlauto, G. M. Ferreira, R. J. Koval, J. M. Pearce, C. R. Wronski, R. W. Collins, M. M. Al-Jassim, and K. M. Jones, Thin Solid Films 455-456, 665 (2004)

${ }^{21}$ R. J. Koval, C. Chen, G. M. Ferreira, A. S. Ferlauto, J. M. Pearce, P. I. Rovira, C. R. Wronski, and R. W. Collins, Appl. Phys. Lett. 81, 1258 (2002).

${ }^{22}$ H. V. Nguyen, Y. Lu, S. Kim, M. Wakagi, and R. W. Collins, Phys. Rev. Lett. 74, 3880 (1995).

${ }^{23}$ S. K. O'Leary, S. Zukotynki, and J. M. Perz, J. Appl. Phys. 78, 4282 (1995).

${ }^{24}$ J. M. Pearce, R. J. Koval, A. S. Ferlauto, R. W. Collins, C. R. Wronski, J. Yang, and S. Guha, Appl. Phys. Lett. 77, 3093 (2000).

${ }^{25}$ H. Sakata, T. Nakai, T. Baba, M. Taguchi, S. Tsuge, K. Uchihashi, and S. Kiyama, Conference Record of the 28th IEEE Photovoltaic Specialist Conference (IEEE, New York, 2000), p. 7.

${ }^{26}$ J. Koval, A. S. Ferlauto, J. M. Pearce, R. W. Collins, and C. R. Wronski, J. Non-Cryst. Solids 299-302, 1136 (2002). 